\title{
Efektivitas Pendidikan Moral Dalam Pembentukan Karakter Siswa Di TK Islam Terpadu Asa Sumbawa
}

\author{
Ramlafatma $^{1}$, Shermina Oruh ${ }^{2}$, Andi Agustang ${ }^{3}$ \\ ${ }^{1}$ Mahasiswa Pascasarjana Program Studi Sosiologi Universitas Negeri Makassar \\ ${ }^{2}$ Dosen Universitas Pejuang Republik Indonesia \\ ${ }^{3}$ Dosen Universitas Negeri Makassar \\ Email: fatmagempar06@gmail.com, shoruh68@gmail.com, andiagust63@gmail.com
}

\begin{abstract}
Moral education is a conscious effort to teach the value of goodness including good behavior, in accordance with normative rules and human behavior in daily life. As individual and social beings in society. Moral means costums, habits, values or life procedures, such a honesty, trustworthiness, fairness, responsibility, respect for fellow human beings, harmony, social solidarity and so on which are packaged in the image of goodness. Moral education is very important to shaping the character. Student in moral learning, especially children, need orientation, for example, that treatment become actions or behavior. The purpose of this study was to (1) determine the effectiveness of moral education in student trhough reading daily prayers and short hadiths in the context of building student character, (2) to know the implementation of moral education methods in student. This type of research is Classroom Action Research or CAR (Classroom Action Research), which is research conducted in a class to find out the consequences of action applied to a research subject in that class. The result of the study show that (1) the educational methods of reading daily prayers and short hadiths in order to shape the character of student is very effective where the abilities possessed by student can show their daily behavior at school. Their morals already reflect Islamic behavior. (2) The learning process carried out by the teacher in collaboration with parents at home is directly interacting with student both during learning and when student are playing.
\end{abstract}

Keywords: Moral Education, Character Building.

\begin{abstract}
Abstrak
Pendidikan moral adalah usaha sadar tentang mengajarkan nilai kebaikan meliputi perilaku baik, sesuai dengan aturan normatif dan juga tentang sikap dan tingkah laku manusia dalam kehidupan sehari-hari.Baik sebagai makhluk individu maupun sebagai makhluk sosial dalam hubungannya dengan masyarakat.Moral berarti adat istiadat, kebiasaan, nilai atau tata cara kehidupan, seperti jujur, dapat dipercaya, adil, bertanggung jawab, penghormatan sesama manusia, kerukunan, kesetiakawanan, solidaritas sosial dan sebagainya yang terkemas dalam citra kebaikan. Pendidikan moral sangatlah penting dalam membentuk karakter seseorang.Peserta didik dalam pembelajaran moral khususnya anak-anak memerlukan orientasi, misalnya teladan yang dapat dilihat dan perlakuan yang dapat dirasakan hingga akhirnya menjadi tindakan atau perilaku.Tujuan penelitian ini untuk (1) Mengetahui efektivitas pendidikan moral pada siswa melalui pembacaan do'a-do'a harian dan hadits-hadits pendek dalam rangka pembentukan karakter siswa, (2) Mengetahui pelaksanaan metode pendidikan moral pada siswa. Jenis penelitian ini adalah Penelitian Tindakan Kelas atau CAR (Classroom Action Research) yaitu penelitian yang dilakukan pada sebuah kelas untuk mengetahui akibat tindakan yang diterapkan pada suatu subyek penelitian di kelas tersebut. Hasil penelitian menunjukkan bahwa (1) Metode pendidikan pembacaan do'a-do'a harian dan hadits-hadits pendek dalam rangka membentuk karakter peserta didik sangat efektif dimana kemampuan yang dimiliki peserta didik dapat memperlihatkan perilaku mereka sehari-hari di sekolah. Moral mereka sudah mencerminkan perilaku yang Islami. (2) Proses pembelajaran yang dilakukan oleh guru bekerjasama dengan orang tua di rumah adalah langsung berinteraksi dengan siswa baik saat pembelajaran berlangsung maupun saat siswa sedang bermain.
\end{abstract}

Kata Kunci: Pendidikan Moral, Pembentukan Karakter

\section{PENDAHULUAN}

Adanya fenomena kekerasan yang terjadi akhir-akhir ini di tengah masyarakat seperti peristiwa tawuran antar pelajar sangat meresahkan karena menyebabkan jatuhnya korban luka-luka bahkan menyebabkan korban
jiwa.Demikian pula dengan berbagai jenis kejahatan lainnya seperti kerusuhan, bentrokan antar agama, suku dan ras, pembunuhan, pemerkosaan dan tindakan kriminalitas lainnya sangat menggangu stabilitas keamanan 
lingkungan masyarakat. (Hartiningsih, Kompas, 2004).

Kejadian-kejadian tersebut dianggap melanggar etika hukum dan moral bangsa Indonesia yang dikenal memiliki karakter ramah, bergotong royong dengan azas persatuan dan kesatuan. Hal tersebut menimbulkan pertanyaan tentang masalah efektivitas pendidikan, dimana pendidikan moral menjadi salah satu bagian pembelajaran dalam pembentukan karakter peserta didik. Pembelajaran moral peserta didik dilakukan agar terbentuk perilaku moral pada anak, khususnya pada anak usia dini yang memerlukan perhatian dan pemahaman terhadap dasar-dasar etika serta berbagai kondisi yang mempengaruhi. Pendidikan moral ini menjadi salah satu topik yang menarik untuk dikaji.

Sekolah sebagai institusi pendidikan formal seharusnya memberi sumbangsih yang besar dalam penerapan pembelajaran moral. TK Islam Terpadu ASA Sumbawa sebagai sekolah pertama yang menerapkan kurikulum Jaringan Sekolah Islam Terpadu (JSIT) di Sumbawa menjadi harapan masyarakat dapat memberikan kontribusi positif bagi pembelajaran moral di sekolah.

Lingkungan sekolah tempat berlangsungnya proses pembelajaran diharapkan memberikan konstribusi yang positif terhadap perkembangan jiwa siswa karena sekolah adalah tempat berlangsungnya pendidikan. Anak belajar untuk menjalani kehidupan melalui interaksi dengan lingkungan. Lingkungan yang kedua setelah lingkungan keluarga dikenal anak adalah lingkungan sekolah. Sekolah mempunyai pengaruh yang sangat besar terhadap perkembangan kepribadian anak didik. Di sekolah siswa melakukan berbagai kegiatan untuk mencapai keberhasilan belajar berupa nilai dan budi pekerti.

Maju mundurnya atau baik buruknya peradaban masyarakat suatu bangsa akan ditentukan oleh bagaimana pendidikan yang dijalani atau yang ditempuh oleh masyarakat bangsa tersebut (Mansyur, 2005 : hal.86). Karena sesungguhnya runtuhnya pendidikan mengakibatkan rendahnya moralitas bangsa yang secara tidak langsung berakibat meningkatnya kriminalitas diberbagai tempat.

Upaya membangun pendidikan sebenarnya juga merupakan upaya membangun moral bangsa yang nantinya dapat memperbaiki watak bangsa yang dijadikan sebagai identitas bangsa Indonesia. Dapat dikatakan bahwa jika dalam suatu masyarakat banyak orang yang rusak moralnya maka akan goncanglah keadaan masyarakat itu (Direktorat Jenderal Pendidikan Agama Islam, 2007: hal. 41).

Program PAUD, telah diprogramkan oleh pemerintah melalui tiga jalur yaitu jalur pendidikan formal, non formal, dan informal. Jalur formal terdiri atas Taman Kanak-kanak (TK), Roudhatul Athfal (RA), atau bentuk lain yang sederajat. Jalur pendidikan nonformal mencakup Kelompok bermain (KB), Taman Penitipan Anak (TPA), atau bentuk lain yang sederajat. Sedangkan jalur pendidikan informal mencakup pendidikan keluarga atau pendidikan yang diselenggarakan oleh lingkungan (Zakiyah Daradjat,1976 : hal. 8). Dengan adanya jalur pendidikan diatas diharapkan upaya pembentukan moral anak, bisa terlaksana lebih baik sehingga nantinya dapat mencetak generasi-generasi penerus yang bermoralitas tinggi.

Masalah moral merupakan masalah yang menjadi kekhawatiran bagi semua orang saat ini. Terlebih bagi para orang tua, mereka pasti ingin memberikan bekal bagi putraputrinya agar kelak sukses di dunia dan selamat di akhirat. Namun banyak orang tua yang belum menyadari bahwasanya pendidikan moral diperoleh pertama kali dari orang tua sendiri, sebab orang tua merupakan orang pertama yang dikenal dan berinteraksi dengan anak. Jadi bisa dikatakan bahwa orang tua merupakan pendidik yang utama dan yang pertama bagi anak.

Seorang pendidik harus bisa menjadi contoh yang baik bagi anak didiknya. Karena pada usia anak-anak mereka akan 
mengidolakan seseorang sebagai tokoh yang hebat yang selanjutnya akan mencontoh perilakunya dalam kehidupan sehari-hari. Anak-anak pada usia dini belajar melalui melihat dari apa yang ada dan yang terjadi di sekitarnya dan bukan lewat mendengarkan nasihat dari pendidiknya (Theo Riyanto dan Martin Handoko, 2004 : 71). Sehingga dapat dikatakan bahwa menjadi model pelaksana moral bagi anak-anak bukan menjadi suatu pilihan bebas, tetapi suatu keharusan yang tak terelakkan sebagai orang tua dan jugapendidik (Theo Riyanto dan Martin Handoko, 2004 : 72).

$$
\text { Sebagai lembaga pendidikan }
$$

prasekolah, keberadaan TK Islam Terpadu ASA dapat menjadi salah satu alternatif bagi para orang tua yang ingin memasukkan anakanaknya untuk mengenal pendidikan sejak dini. Melalui kegiatan belajar mengajar di TK Islam Terpadu ASA maka anak senantiasa diperkenalkan dan ditanamkan mengenai nilainilai moral, misalnya interaksi anak dengan sesama akan menjadikan anak lebih bisa mengerti arti bagaimana pentingnya menjalin hubungan yang baik dengan orang lain.

TK Islam Terpadu ASA menanamkan pendidikan moral melalui pembiasaan perilaku dalam kehidupan sehari-hari. Penanaman pendidikan moral tersebut sifatnya saling mengisi serta menyempurnakan pendidikan moral yang diberikan oleh orang tua di rumah. Sehingga TK Islam Terpadu ASA dapat memenuhi harapan orang tua yaitu bahwa sekolah bukanlah sekedar tempat untuk menuangkan ilmu pengetahuan ke otak peserta didik tetapi lebih dari itu dapat mendidik dan membentuk karakter anak.

Dari latar belakang di atas, membuat peneliti tertarik untuk melakukan pendalaman secara langsung tentang "Efektivitas Pendidikan Moral Dalam Pembentukan Karakter Anak Di TK Islam Terpadu ASA Sumbawa.

Rumusan masalah dalam penelitian ini adalah (1) Bagaimana efektivitas pendidikan moral pada siswa melalui pembacaan do'a-do'a harian dan hadits-hadits pendek dalam rangka pembentukan karakter siswa? (2) Bagaimana pelaksanaan metode pendidikan moral pada siswa?

Tujuan penelitian ini untuk (1) Mengetahui efektivitas pendidikan moral pada siswa melalui pembacaan do'a-do'a harian dan hadits-hadits pendek dalam rangka pembentukan karakter siswa, (2) Mengetahui pelaksanaan metode pendidikan moral pada siswa

\section{METODE PENELITIAN}

Metode penelitian yang digunakan adalah Penelitian Tindakan Kelas (PTK) atau Class Action Research (CAR) yang berarti penelitian pada sebuah kelas untuk mengetahui akibat tindakan yang diterapkan pada suatu subyek penelitian di kelas tersebut. Penelitian tindakan ini melibatkan guru dalam empat tahap, yaitu : (1) mengidentifikasi fokus permasalahan, (2) mengumpulkan data, (3) analisis dan interpretasi data, dan (4) mengembangkan rencana tindakan. Penelitian tindakan dapat berupa percobaan untuk mengangkat ide ke dalam praktek langsung agar dapat melakukan perbaikan yang berpengaruh dalam situasi nyata (Kemmis seperti dikutip Hopkins, 1993:45). Menurut Supriyadi dkk, (2010: 28-53) bahwa beberapa karakteristik PTK adalah : (1) Masalahnya nyata, tidak dicari-cari, bersifat kontekstual, (2) Berorientasi pada pemecahan masalah, (3) Data diambil dari berbagai sumber, (4) Bersifat siklik yaitu penelitian-tindakan-penelitiantindakan, (5) Partisipatif, dilakukan sendiri, (6) Kolaboratif, dibantu teman sejawat dan orang tua di rumah. Populasi yang digunakan adalah seluruh siswa kelas B dengan jumlah responden sebanyak 10 orang. Do'a-do'a harian yang diajarkan pada siswa TK Islam Terpadu ASA adalah : (1) Do'a belajar, (2) Do'a masuk dan keluar WC, (3) Do'a sebelum dan sesudah makan, (4) Do'a untuk orang tua, (5) Do'a keselamatan dunia dan akhirat. Sedangkan hadits-hadits pendek yang dihafalkan adalah : (1) Hadits tersenyum, (2) Hadits kebersihan, (3) Hadits larangan marah, (4) Hadits ibadah, (5) 
Hadits senang berbagi.

Penelitian dilakukan dengan 4 (empat) tahap pengamatan yaitu : (1) Prasiklus, sebelum perlakuan diberikan, (2) Siklus I, setelah 2 minggu perlakuan diberikan, (3) Siklus II, setelah 4 minggu perlakuan diberikan, dan (4) Siklus III, setelah 6 minggu perlakuan diberikan. Setelah do'a harian dan hadits sudah dihafalkan dan diberi pemahaman, setiap responden diberi tugas untuk mengamalkan dalam interaksi mereka sehari-hari baik di rumah maupun di sekolah. Guru dan orang tua berkolaborasi mengamati perubahan setiap responden dengan cara mencatat hasil tugas yang diberikan kepada setiap responden. Tugastugas yang diberikan antara lain: membaca do'a sebelum memulai pelajaran, membaca do'a ketika masuk dan keluar WC, membaca do'a sebelum dan sesudah makan, membaca do'a untuk orang tua setelah shalat, membaca do'a keselamatan dunia dan akhirat setelah shalat, tersenyum di pagi hari saat memasuki gerbang sekolah, menjaga kebersihan, menahan emosi saat ada gangguan teman, shalat tepat waktu dan berbagi makan dan minuman dengan teman sekelasnya.

\section{HASIL DAN PEMBAHASAN}

Dari penelitian ini diperoleh data bahwa dari 10 orang siswa yang dijadikan responden, setelah diberi pemahaman tentang do'a-do'a harian dan hadits-hadits pendek, mereka mampu mengamalkan nilai-nilai moral yang terkandung dalam do'a dan hadits yang dihafalkan. Hal ini terlihat pada tabel berikut:

Tabel 1. Rekapitulasi Hasil Penelitian Per

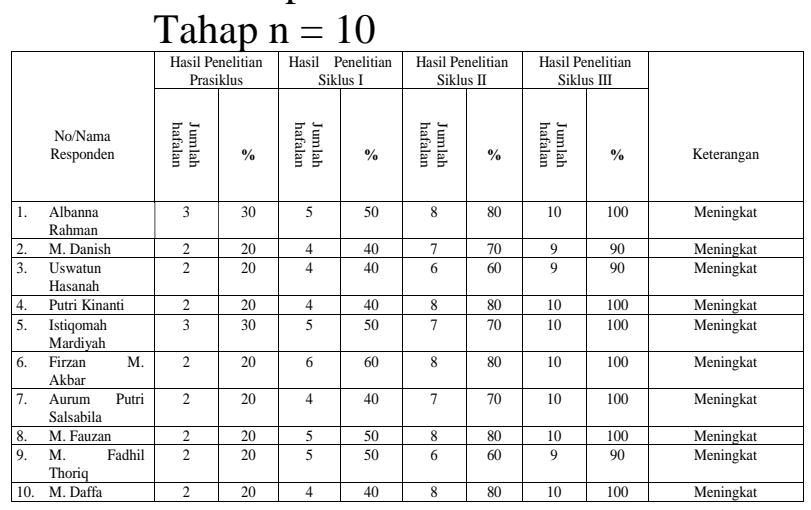

Berdasarkan data dapat diketahui bahwa tingkat pemahaman para siswa terhadap do'a-do'a harian dan hadits-hadits pendek sebagai berikut:

1. Pada Prasiklus terdapat 8 orang siswa yang hafalan do'a harian dan haditsnya baru 2 dari 10 yang ditargetkan dan 2 orang siswa yang hafalan do'a harian dan haditsnya sudah 3 dari 10 yang ditargetkan. Mereka dari kelas A berbeda kemampuan menghafalnya.

2. Pada Siklus I terdapat 1 orang siswa meningkat hafalannya sebanyak $40 \%$ yaitu Firzan M. Akbar (responden 6), dan 2 orang siswa yang menambah hafalannya sebanyak $30 \%$ yaitu M. Fauzan (responden 8) dan M. Fadhil Thoriq (responden 9) serta terdapat 7 orang siswa meningkat hafalannya sebesar $20 \%$.

3. Pada Siklus II terdapat 2 orang siswa yang meningkat hafalannya sebesar $40 \%$ yaitu Putri Kinanti (responden 4) dan M. Daffa (responden 10), 4 orang siswa yang meningkat hafalannya sebesar $30 \%$ yaitu Albanna Rahman (responden 1), M. Danish (responden 2), Aurum Putri Salsabila (responden 7) dan M. Fauzan (responden 8), sedangkan yang meningkat hafalannya sebesar $20 \%$ terdapat 3 orang siswa yaitu Uswatun Hasanah (responden 3), Istiqomah Mardiyah (responden 5) dan Firzan M. Akbar (responden 6) dan 1 orang yang hanya meningkat hafalannya sebesar $10 \%$ yaitu M. Fadhil Thoriq (responden 9).

4. Pada Siklus III penelitian ini terdapat 4 orang siswa yang meningkat hafalannya sebesar 30\% yaitu responden 3, 5 dan 7 . Sedangkan 6 responden lainnya hafalan do'a harian dan haditsnya meningkat sebesar $20 \%$.

Dari tabel 1 dapat disebutkan bahwa jumlah hafalan siswa meningkat dari setiap siklus penelitian. Hal ini dapat dilihat dari grafik berikut: 


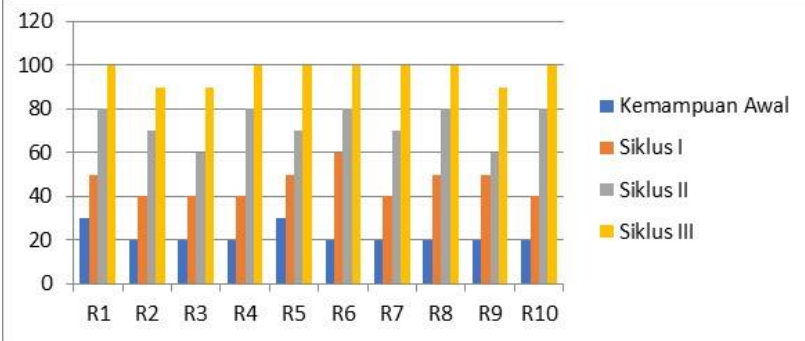

Grafik. Rekapitulasi Hasil Penelitian Per Tahap $\mathrm{n}=10$

Pada tiga kali siklus penelitian, kemampuan siswa yang awalnya berbeda-beda, setelah diberi pemahaman tentang implementasi dari do'a dan hadits yang dihafalkan, akhirnya bisa memberi hasil yang relatif sama. Hal ini dapat dilihat juga dari perilaku mereka seharihari di sekolah. Moral mereka sudah mencerminkan perilaku yang Islami.

\section{HASIL DAN PEMBAHASAN} Pendidikan Moral

Pendidikan moral merupakan bagian yang tidak terpisahkan dalam proses pendidikan. Beberapa hal yang berkaitan dengan pendidikan moral, yaitu: (1) Pendidikan karakter yang merupakan pendidikan yang langsung bersentuhan dengan perkembangan moral anak; (2) Klarifikasi nilai yang merupakan proses memberikan bantuan kepada setiap anak untuk memahami dan menyadari tujuan hidup serta mengklarifikasi bentukbentuk perilaku apa yang layak dikerjakan.

Menurut Durkheim, dalam Pendidikan Moral (1990:39), terjemahan Lukas Ginting, bahwa manusia sebagai makhluk terbatas, secara fisik merupakan bagian dari alam semesta, secara moral merupakan bagian dari masyarakat. Semakin kompleks suatu masyarakat, semakin sulit pula bagi moralitas untuk bisa terlaksana berdasarkan mekanisme otomatik. Keadaan lingkungan tidak pernah sama, karena itu sebagai akibatnya, dalam penerapan moralitas diperlukan pemahaman intelektual. Selanjutnya Durkheim menganggap bahwa bangsa harus menggantungkan harapan yang besar kepada guru. Hal ini bukan hanya karena pendidikan intelektual yang dapat ia berikan, namun adanya kesempatan yang besar untuk menanamkan semacam pengaruh pada anak yang tidak dapat digantikan oleh apapun (Durkheim, dalam Lukas Ginting, 1990:173).

Melihat tahap masa anak-anak menurut Durkheim, tahap pertama hampir seluruhnya berlangsung dalam keluarga, dan tahap kedua berlangsung di sekolag dasar. Dan pembahasan mengenai pendidikan moral, akan memusatkan perhatian pada tahap yang kedua, karena tahap ini merupakan tahap yang kritis dalam pembentukan sikap moral. Jika tahap kedua ini berlalu, dan belum diletakkan dasar-dasar moralitas, maka dasar-dasar moralitas tersebut tidak akan pernah tertanam dalam diri anak. Maka di Indonesia sebaiknya menanamkan pendidikan mengenai moralitas sejak dini pada anak.

\section{Pengembangan Kebiasaan Berperilaku Yang Baik Di Sekolah}

Perkembangan moral anak tidak terlepas dari lingkungan di luar rumah. Pendidikan moral pada lembaga pendidikan formal dimulai ketika anak-anak mengikuti pendidikan pada taman kanak-kanak. Pengalaman yang diperoleh anak-anak dari taman kanak-kanak memberikan pengaruh positif pada perkembangan anak selanjutnya.

Berbicara pendidikan sekolah merupakan pembicaraan mengenai kehidupan karena pendidikan adalah proses yang dilakukan setiap individu menuju ke arah yang lebih baik sesuai dengan potesi kemanusiaan. Driyarkara merumuskan pendidikan sebagai memanusiakan manusia muda, membentuk manusia muda untuk berkembang menjadi manusia utuh, bermoral, bersosial, berkepribadian dan berpengetahuan. Sama halnya pendidikan yang menciptakan makhluk baru menurut Durkheim. Lingkungan sekolah merupakan asosiasi yang lebih luas daripada keluarga atau teman-teman. Lingkungan sekolah tidak berasal dari hubungan darah, bukan juga dari pilihan bebas, tetapi dari pertemuan yang tidak dapat dielakkan yang dikumpulkan berdasarkan usia dan berbagai kondisi sosial yang hampir sama. Serta sebagai sarana untuk melatih anak dalam kehidupan 
kolektif (kelompok), kebutuhan untuk terikat kepada kekuatan-kekuatan kolektif.

Dengan diberikannya pendidikan moral bagi anak diharapkan dapat merubah perilaku anak, sehingga jika sudah dewasa lebih bertanggung jawab dan menghargai sesamanya dan mampu menjawab tantangan jaman yang cepat berubah. Di sinilah pentingnya nilai-nilai moral yang berfungsi sebagai media transformasi manusia Indonesia agar lebih baik, memiliki keunggulan dan kecerdasan di semua sektor kehidupan baik kecerdasan intelektual, kecerdasan emosional, kecerdasan sosial maupun kecerdasan spiritual. Peran orang tua dan guru hanya sebatas memberi hal yang terbaik sesuai dengan jiwa dan jaman yang dihadapi saat ini, agar kelak anak dapat mengatasi permasalahannya sendiri dan memiliki keunggulan moral yang baik dan luhur.

\section{KESIMPULAN}

1. Metode pendidikan moral pada siswa melalui pembacaan do'a-do'a harian dan hadits-hadits pendek efektif memberikan dampak dalam pembentukan karakter siswa. Kemampuan yang dimiliki siswa yang dijadikan responden dapat memperlihatkan perilaku mereka sehari-hari di sekolah dengan menampakkan moral yang mencerminkan perilaku yang Islami.

2. Hasil pelaksanaan metode pendidikan moral pada siswa mengalami peningkatan pada setiap tahap kegiatan penelitian. Proses pembelajaran yang dilakukan para guru dengan mendekatkan diri langsung kepada siswa baik saat pembelajaran berlangsung maupun saat siswa sedang bermain membantu siswa untuk lebih berkonsentrasi dalam belajar dan dapat lebih memahami do'a-do'a harian dan hadits-hadits pendek yang diberikan gurunya.

\section{SARAN}

1. Diperlukan usaha untuk membentuk anak menjadi pribadi yang bermoral dengan memberikan perlakuan yang adil, hormat dan penuh kasih sayang. Guru menjadi contoh atau tokoh panutan dan membetulkan perilaku yang salah pada siswa dengan bahasa dan perilaku yang mudah dimengerti siswa.

2. Dibutuhkan peran keluarga dalam membentuk karakter anak melalui pendidikan dari lingkungan keluarga yang bahagia sebagai ruang sosialisasi terdekat bagi anak baik secara fisik maupun psikis.

\section{UCAPAN TERIMA KASIH}

Ucapan terima kasih diberikan kepada pihak-pihak yang telah memberi dukungan baik materil maupun non materil, diantaranya:

1. Kepala Sekolah dan guru-guru TK Islam Terpadu ASA Sumbawa yang telah memberi ruang dan waktu bagi terlaksananya penelitian ini.

2. Para orang tua dari responden yang telah membantu melakukan pengamatan pada perilaku anak di rumah.

3. Lembaga Perlindungan Anak (LPA) Kabupaten Sumbawa yang telah memberi saran dan masukan sehingga penelitian ini dapat berjalan lancar sesuai harapan.

\section{DAFTAR PUSTAKA}

David Hopkins. 2003. A Teacher's Guide in Classroom Research. Open University Press. Buckingham.

Direktorat Jenderal Pendidikan Agama Islam. 2007. Petunjuk Teknis Pembinaan Konseling. Kementerian Agama Republik Indonesia.

Driyarkara, N. 2006. Esai-esai Filsafat Pemikir yang Terlibat dalam Perjuangan Bangsa. Penerbit PT. Gramedia Pustaka Utama. Jakarta.

Durkheim, E. 1973. Moral Education A Study in the Theory and Application of The Sociology of Education, alih bahasa: Everest $\mathrm{K}$ Wilson and Herman Schnurer The Free Press of Glencoe, New York.

Ginting, L. 1990. Pendidikan Moral: Suatu Studi Teori Dan Aplikasi Sosiologi 
Pendidikan. Penerbit Erlangga. Jakarta.

Handoko, M. 1992. Motivasi Perilaku. Penerbit Rineka Cipta. Jakarta.

Mansur. 2005. Pendidikan Anak Usia Dini Dalam Islam. Yogyakarta: Pustaka Pelajar.

Maria Hartiningsih. 2004. Mungkinkah Membangun Republik Tanpa Kekerasan. Kompas, Sabtu 3 Juli. p.41.

Riyanto, T. 2004. Pendidikan Anak Usia Dini: Tuntutan Psikologis dan Pedagogis Bagi Pendidik dan Orang Tua. Penerbit PT. Gramedia Widya Sarana Indonesia. Jakarta.

Supriyadi dkk. 2010. Modul Pendidikan dan Latihan Profesi Guru Rayon 9 Universitas Negeri Jakarta (UNJ). Jakarta.

Zakiyah, D. 1976. Guru Dan Anak Didik Dalam Interkasi Edukatif. Penerbit Rineka Cipta. Jakarta. 